\title{
PERBEDAAN DAYA TAHAN NON SPESIFIK LIMA SPESIES IKAN AIR TAWAR TERHADAP INFEKSI Aeromonas hydrophila
}

\section{DIFFERENCE OF NON SPESIFIC DEFENCE OF FIVE FRESHWATER FISH SPECIES AGAINST Aeromonas hydrophila}

\author{
H. Syakuri", Triyanto"), dan K.H. Nitimulyo")
}

\begin{abstract}
Fish naturally has a non-specific defense against several pathogens. The non-specific defense is anatomical and physiological function, that varies according to genetical and environmental factors. The differences of non-specific defense against Aeromonas hydrophila infection were studied in blackfin pacu (Colossoma macropomum), gouramy (Osphronemus goramy), common carp (Cyprinus carpio), african cattish (Clarias gariepinus), and red nile tilapia (Oreochromis sp.). This study also examined the differences on several parameters of non-specific defense, including differentiation anc number of leucocytes, serum total, titer of antibody, and antibacterial activity of skin mucus.
\end{abstract}

The fishes were intramuscularly infected at the median lethal doses for common carp $(7,4 \mathrm{x}$ $10^{8}$ cfufiish). Pathological changes, survival rate, and mean time to death were observed every day. The observation of non-specific defense parameters were carried out prior and at seven day after infection.

The results showed that blackfin pacu was the most resistant species againts A. hydrophila infection. African catfish and red nile tilapia were more resistant than gouramy and common carp. The antibody titer and percentage of trombocytes were the causative factors for the difference of the resistence againts A. hydrophila. The five fish species also showed differences on leucocytes number, monocytes and eosinophils percentages, and serum total, but they did not showed the differences of neutrophil percentage. The skin mucus of all fish species did not exhibited antibacterial activity against $A$. hydrophila. This study also found the increase in antibody titer and leucocytes number after $A$. hydrophila infection.

Key Words : Aeromonas hydrophila, Clanias gariepinus, Colossoma macropomum, Cyprinus carpio, non specific defense, Oreochromis sp., Osphronemus goramy

\section{Pengantar}

Aeromonas hydrophila merupakan bakteri patogen oportunistik pada ikan (Roberts, 1993; Post, 1983) yang mampu hidup dan berkembang pada kisaran kondisi lingkungan yang lebar. Bakteri ini mampu berkembang pada perairan lotik dan lentik, temperatur $4-45^{\circ} \mathrm{C}, \mathrm{pH} 5,2-9,8$, dan berbagai tingkat salinitas kecuali kondisi ekstrim (100 ppt) (Hazen dkk.,
1978). Bakteri ini mampu berkembang dengan cepat pada perairan yang mempunyai kandungan bahan organik tinggi (Roberts, 1993). Hal tersebut mengakibatkan bakteri ini dapat menyerang berbagai spesies ikan terutama di perairan tawar.

Spesies ikan tropis yang banyak terserang A. hydrophila adalah Karper dan Lele (Sarono dkk. 1993), bakteri ini juga mampu menimbulkan penyakit pada

\footnotetext{
"Staf pengajar Program Sarjana Perikanan dan Kelautan Universitas Jenderal Soedirman, Karangwangkal

Punwokerto

TStaf Pengajar Jurusan Perikanan Fakultas Pertanian UGM, Jalan Sosio Justisia, Bulaksumur, Yogyakarta
} 
Gurami (Supriyadi dkk. 1995), dan Nila merah (Supriyadi dkk. 1998). Llobrera dan Gacutan (1987) melaporkan bahwa bakteri ini juga menyerang Ophiocepalus striatus, Clarias batrachus, Carassius carassius, dan Glossogobius giurus.

Ikan mempunyai daya tahan alami yang bersifat nonspesifik terhadap organisme patogen (Schaperclaus, 1992; Smith, 1982; Anderson, 1974) yang dapat berupa pertahanan fisik (mekanik), kimia, hormonal, seluler dan humoral. Daya tahan alami ini dipengaruhi oleh faktor genetik dan lingkungan, sehingga terdapat kemungkinan tingkatannya berbeda-beda karena perbedaan strain, lingkungan permeliharaan, spesies maupun famili (Schaperclaus, 1992; Brown dan Gratzek, 1980; Haripoemomo, 1986; Bell dan Lightner, 1984; Bastiawan dkk., 1995; Madhavi, 1980; Britz dkk., 1985). Faktorfaktor daya tahan alami ikan antara lain jaringan epitelia, endotelia, sekresi lambung dan usus (Schaperclaus, 1992), kulit, sisik (Smith, 1982; Ventura dan Grizzle, 1987), lendir (Wechsler, 1984; Hjelmeland dkk., 1983; Ingram, 1980), selsel fagosit dan antibodi alami (Ingram, 1980; Schaperclaus, 1992).

Pengetahuan tentang perbedaan tingkat daya tahan ikan terhadap suatu penyakit dapat digunakan dalam seleksi ikan yang akan dibudidayakan baik jenis maupun individunya (Sindermann, 1977). Oleh karena itu penelitian mengenai perbedaan daya tahan beberapa spesies ikan budidaya, seperti Bawal air tawar, Gurami, Karper, Lele Dumbo dan Nila merah, terhadap infeksi A. hydrophila perlu dilakukan sebagai salah satu bahan pertimbangan dalam seleksi spesies ikan pada budidaya polikultur maupun pola pergiliran budidaya monokultur.

\section{Bahan dan Metode}

Jenis ikan yang digunakan dalam penelitian ini adalah Karper $(14,58 \pm 2,29$ g). Bawal air tawar (12,48 $\pm 3,29 \mathrm{~g})$, Nila merah $(14,81 \pm 2,39 \mathrm{~g})$, Lele Dumbo
$(12,82 \pm 2,05 \mathrm{~g})$, dan Gurami $(15,82 \pm 1,99$ g). Jenis ikan tersebut dianggap sebagai perlakuan dengan masing-masing tiga ulangan. Kelima jenis ikan tersebut kemudian diinfeksi secara intramuskular dengan median lethal dose (LD 50 ) $A$. hydrophila pada Karper $\left(7,4 \times 10^{8}\right.$ cfulekor).

Ikan yang sudah diinfeksi kemudian dipelihara selama 15 hari dalam bak berisi \pm 144 liter air. Selama pemeliharaan ikan tidak diberi pakan, sedangkan pergantian air dan aerasi dilakukan dengan memberikan aliran air $(15,5 \pm 2,82$ Ljarn).

Perkembangan gejala ekstemal dan mortalitas diamati setiap hari pukui 10.00 WIB. Sedangkan parameter daya tahan non spesifik, yang meliputi jumlah dan diferensiasi leukosit, persentase serum, titer antibodi, dan antibakterial pada lendir, diamati sebelum dan tujuh hari sesudah infeksi. Parameter kualitas air, yang meliputi oksigen terlarut, karbondioksida bebas, alkalinitas, $\mathrm{pH}$, suhu air, dan suhu udara, diamati pada awal dan akhir penelitian.

Pengambilan darah ikan dilakukan dengan memotong okor (enam ekor) dan menampung darah yang keluar. Sampel darah yang akan digunakan untuk pengamatan jumlah dan diferensiasi leukosit, serta persentase serum dicampur dengan EDTA sebagai antikoagulan. Sedangkan sampel darah yang digunakan untuk titer antibodi disimpan disam? refrigerator selama satu malam. Penghitungan jumlah leukosit dan persentase serum dilakukan dengan metode Klontz (1994) dan Anonim (1997), diferensiasi leukosit (Anonim 1997), titer antibodi (Anonim, 1997 dan Roberson, 1990). Sedangkan lendir antibakterial diuji menggunakan paper disk (Jutono dkk. 1980).

\section{Hasil dan Pombahasan}

$\begin{array}{rrr}\text { Pengamatan } & \text { gejala } & \text { oksternal } \\ \text { menunjukkan } & \text { adanya } & \text { perbedaan }\end{array}$


perkembangan gejala penyakit. Gejala ekstemal pertama kali teramati pada Karper, yaitu terjadinya peradangan di daerah sekitar infeksi yang semakin lama semakin membesar. Gejala yang sama juga terjadi pada Gurami, Lele Dumbo, dan Nila merah, namun peradangan pada Karper mengakibatkan pembengkakan sedangkan pada tiga spesies ikan yang lain tidak mengakibatkan pembengkakan. Pada ikan yang bertahan hidup, bagian tubuh yang mengalami pemborokan akan mengelupas dan akhimya tertutup kembali karena pembentukan jaringan baru. Bawal air tawar, berbeda dengan empat spesies yang lain, tidak menunjukkan gejala eksternal yang berarti.

Lima spesies ikan yang diuji menunjukkan perbedaan yang signifikan pada tingkat sintasan akibat infeksi A. hydrophila. Tabel 1 menunjukkan bahwa Bawal air tawar merupakan spesies yang paling tahan terhadap infeksi bakteri tersebut, dengan tingkat sintasan $100 \%$. Spesies ikan yang paling sensitif adalah Karper dan Gurami, sedangkan Lele Dumbo dan Nila merah tampak lebih tahan terhadap serangan $A$. hydrophila.

Rerata waktu kematian juga menunjukkan bahwa kematian Karper terjadi paling cepat (22,72 jam), kemudian disusul oleh Nila merah, Gurami, dan Lele Dumbo. Tabel 2 juga menunjukkan bahwa, meskipun tingkat sintasan Nila merah $(37,77 \%)$ lebih tinggi dibandingkan Gurami $(4,77 \%)$ namun terjadinya kematian justru lebih copat $(31,32$ jam).

Perbedaan tingkat daya tahan lima spesies ikan uji kemungkinan dipengaruhi oleh titer antibodi dan persentase trombosit. Tabel 3 menunjukkan tingkat titer antibodi lima spesies ikan uji sebelum dan tujuh hari sesudah infeksi. Pengamatan titer antibodi sebelum infeksi menunjukkan Bawal air tawar mempunyai titer antibodi yang paling tinggi, diikuti oleh Lele Dumbo dan Nila merah serta Karper dan Gurami.

Tabel 1. Tingkat sintasan lima spesies ikan akibat infeksi $\boldsymbol{A}$. Hydrophila

\begin{tabular}{|c|c|c|c|c|c|c|}
\hline \multirow{2}{*}{ No } & \multirow{2}{*}{ Spesies } & \multicolumn{4}{|c|}{ Tingkat sintasan (\%) } & \multirow[t]{2}{*}{ Rerata } \\
\hline & & Kontrol & 1 & II & III & \\
\hline 1. & Bawal a.t. "(C. macropomum) & 100,00 & 100,00 & 100,00 & 100,00 & $100,00^{2}$ \\
\hline 2. & Gurami (O. goramy) & 93,33 & 0,00 & 7,15 & 7,15 & $4,77^{c}$ \\
\hline 3. & Karper (C. carpio) & 100,00 & 0,00 & 6,70 & 0,00 & $2,23^{c}$ \\
\hline 4. & Lele Dumbo (C. gariepinus) & 93,33 & 42,86 & 28,61 & 92,89 & $54,79^{\circ}$ \\
\hline 5. & Nila merah (Oreochromis sp.) & 100,00 & 46,70 & 53,30 & 13,30 & $37,77^{\mathrm{bc}}$ \\
\hline
\end{tabular}

Tabel 2. Rerata waktu kematian (RWK) lima spesies ikan akibat infeksi A. hydrophila

\begin{tabular}{llcccc}
\hline \multirow{2}{*}{ No } & \multicolumn{1}{c}{ Spesies } & \multicolumn{3}{c}{ Rerata waktu kematian (jam) } & Rerata \\
\cline { 3 - 5 } & & \multicolumn{1}{c}{ I } & - & III & \\
\hline 1. & Bawal a.t." (C. macropomum) & - & - & - & \\
2. & Gurami (O. goramy) & 42,93 & 51,00 & 46,21 & $46,71^{\text {ab }}$ \\
3. & Karper (C. carpio) & 23,40 & 23,57 & 21,20 & $22,72^{\text {b }}$ \\
4. & Lele Dumbo (C.gariepinus) & 80,56 & 48,64 & 38,00 & $55,73^{\circ}$ \\
5. & Nila merah (Oreochromis sp.) & 24,88 & 43,71 & 25,38 & $31,32^{\circ}$ \\
\hline
\end{tabular}

Keterangan : Rerata dengan huruf superscript yang sama menunjukkan tidak berbeda nyata : air tawar 
Syakuri, dkk., 2003

Tabel 3. Tingkat titer antibodi lima spesies ikan terhadap A. hydrophila sebelum dan tujuh hari sesudah infeksi

\begin{tabular}{llccc}
\hline \multirow{2}{*}{ No } & \multicolumn{1}{c}{ Spesies } & \multicolumn{2}{c}{ Titer antibodi } & Peningkatan \\
\cline { 2 - 4 } & & Sebelum & Sesudah & $(\mathbf{x})$ \\
\hline 1. & Bawal a.t." (C. macropomum) & $2^{6,60}$ & $2^{8,33}$ & 3,33 \\
2. & Gurami (O. goramy) & $2^{2,00}$ & ND & - \\
3. & Karper (C. Carpio) & $2^{2,60}$ & ND & - \\
4. & Lele Dumbo (C. gariepinus) & $2^{3,60}$ & $2^{11,60}$ & $256,00^{*}$ \\
5. & Nila merah (Oreochromis sp.) & $2^{3,60}$ & $2^{12,30}$ & $426,67^{*}$ \\
\hline
\end{tabular}

Keterangan : Rerata dengan huruf superscript yang sama menunjukkan tidak berbeda nyata - : air tawar

ND: Not Determined

Tabel 4. Rerata trombosit (\%) lima spesies ikan sebelum dan tujuh hari sesudah infeksi

\begin{tabular}{llccc}
\hline \multirow{2}{*}{ No } & \multicolumn{1}{c}{ Spesies } & \multicolumn{2}{c}{ Rerata trombosit (\%) } & Peningkatan \\
\cline { 3 - 4 } & & Sebelum & Sesudah & $(\%)$ \\
\hline 1. & Bawal a.t.(C. macropomum) & $37,73 \pm 4,63^{\circ}$ & $40,70 \pm 3,48^{\circ}$ & 2,97 \\
2. & Gurami (O. goramy) & $6,12 \pm 0,05^{\mathrm{d}}$ & $\mathrm{ND}$ & - \\
3. & Karper (C. Carpio) & $5,68 \pm 1,14^{\mathrm{d}}$ & $\mathrm{ND}$ & - \\
4. & Lele Dumbo (C. gariepinus) & $26,49 \pm 3,38^{\mathrm{b}}$ & $13,35 \pm 5,73^{\circ}$ & $-13,35$ \\
5. & Nila merah (Oreochromis sp.) & $14,40 \pm 2,02^{\circ}$ & $19,69 \pm 11,43^{\mathrm{a}}$ & 5,29 \\
\hline
\end{tabular}

Keterangan : Rerata dengan huruf superscript yang sama menunjukkan tidak berbeda nyata

- : air tawar

ND: Not Determined

Antibodi alami dapat mengindikasikan bahwa suatu spesies ikan tersebut telah berinteraksi dengan patogen yang sama (Fujihara dan Tramel, 1970 dalam Ingram, 1980) atau dengan organisme yang bereaksi silang dengan patogen (Troasi, 1975 dalam Ingram, 1980). Leblanc dkk. (1981) melaporkan adanya reaksi silang antara A. hydrophila dan A. sobria.

Lele Dumbo dan Nila merah mengalami peningkatan titer antibodi akibat infeksi yang lebih tinggi dibandingkan Bawal air tawar. Hal tersebut mengindikasikan bahwa infeksi saat penelitian berfungsi sebagai booster dari infeksi alami, yang dapat mengakibatkan pembentukan antibodi berjalan cepat dengan konsentrasi yang tinggi (Ellis, 1988).

Tabel 4 menunjukkan Bawal air tawar mempunyai persentase trombosit yang paling tinggi, diikuti oleh Lele Dumbo, Nila merah, Gurami, dan Karper. Trombosit mempunyai peranan penting dalam penutupan luka dan menghambat penetrasi bakteri (Roberts, 1978 dan Anderson, 1974). Infeksi yang dilakukan tidak mengakibatkan perubahan yang signifikan pada persentase trombosit.

Tabel 5 menunjukkan Gurami, Nila merah, dan Karper mempunyai persentase limfosit yang lebih tinggi dibandingkan Bawal air tawar dan Lele Dumbo. Limfosit merupakan salah satu jenis leukosit yang berperan penting dalam pembentukan antibodi, yaitu dengan membentuk antibodi dan sel-sel memori (Ellis, 1988 dan KennedyStoskopt, 1993). Namun perbedaan persentase limfosit pada penelitian ini tidak mempengaruhi daya tahan terhadap infeksi A. hydrophila. 
Tabel 5. Rerata limfosit (\%) lima spesies ikan sebelum dan tujuh hari sesudah infeksi

\begin{tabular}{|c|c|c|c|c|}
\hline \multirow{2}{*}{ No } & \multirow{2}{*}{ Spesies } & \multicolumn{2}{|c|}{ Rerata limfosit (\%) } & \multirow{2}{*}{$\begin{array}{c}\text { Peningkatan } \\
(\%)\end{array}$} \\
\hline & & Sebelum & Sesudah & \\
\hline 1. & Bawal a.t." (C. macropomum) & $51,87 \pm 8,04^{b}$ & $54,19 \pm 5,84^{b}$ & 2,32 \\
\hline 2. & Gurami (O. goramy) & $81,65 \pm 1,61^{a}$ & ND & - \\
\hline 3. & Karper (C. carpio) & $72,08 \pm 7,84^{a}$ & ND & - \\
\hline 4. & Lele Dumbo (C. gariepinus) & $54,50 \pm 4,23^{b}$ & $72,44 \pm 0,43^{a}$ & $17,94^{\circ}$ \\
\hline 5. & Nila merah (Oreochromis sp.) & $73,82 \pm 3,58^{a}$ & $65,90 \pm 7,55^{\circ}$ & $-7,92$ \\
\hline
\end{tabular}

Tabel 6. Rerata monosit (\%) lima spesies ikan sebelum dan tujuh hari sesudah infeksi

\begin{tabular}{|c|c|c|c|c|}
\hline \multirow{2}{*}{ No } & \multirow{2}{*}{ Spesies } & \multicolumn{2}{|c|}{ Rerata monosit (\%) } & \multirow{2}{*}{$\begin{array}{c}\text { Peningkatan } \\
(\%)\end{array}$} \\
\hline & & Sebolum & Sesudah & \\
\hline 1. & Bawal a.t."(C. macropomum) & $5,88 \pm 2,55^{c}$ & $1,86 \pm 1,21^{b}$ & $-4,02$ \\
\hline 2. & Gurami (O. goramy) & $7,92 \pm 0,93^{b c}$ & ND & - \\
\hline 3. & Karper (C. carpio) & $13,02 \pm 3,71^{2 b}$ & ND & - \\
\hline 4. & Lele Dumbo (C. gariepinus) & $16,00 \pm 5,29^{a}$ & $7,52 \pm 2,60^{\circ}$ & $-8,48$ \\
\hline 5. & Nila merah (Oreochromis sp.) & $8,64 \pm 1,57^{6 c}$ & $11,51 \pm 4,83^{a}$ & 2,87 \\
\hline
\end{tabular}

Tabel 7. Rerata neutrofil (\%) lima spesies ikan sebelum dan tujuh hari sesudah infeksi

\begin{tabular}{|c|c|c|c|c|}
\hline \multirow{2}{*}{ No } & \multirow{2}{*}{ Spesies } & \multicolumn{2}{|c|}{ Rerata neutrofil (\%) } & \multirow{2}{*}{$\begin{array}{c}\text { Peningkatan } \\
(\%)\end{array}$} \\
\hline & & Sebelum & Sesudah & \\
\hline 1. & Bawal a.t." (C. macropomum) & $2,46 \pm 1,82^{\circ}$ & $0,74 \pm 0,38^{2}$ & $-1,72$ \\
\hline 2. & Gurami (O. goramy) & $1,98 \pm 0,86^{a}$ & ND & - \\
\hline 3. & $\operatorname{Karper}$ (C. carpio) & $4,65 \pm 2,01^{\circ}$ & ND & - \\
\hline 4. & Lele Dumbo (C. gariepinus) & $3,00 \pm 1,91^{a}$ & $2,73 \pm 1,44^{3}$ & $-0,27$ \\
\hline 5. & Nila merah (Oreochromis sp.) & $1,31 \pm 0,45^{a}$ & $1,53 \pm 0,48^{a}$ & 0,22 \\
\hline
\end{tabular}

Tabel 8. Rerata eosinofil (\%) lima spesies ikan sebelum dan tujuh hari sesudah infeksi

\begin{tabular}{llccc}
\hline \multirow{2}{*}{ No } & \multicolumn{1}{c}{ Spesies } & \multicolumn{2}{c}{ Rerata eosinofil (\%) } & Peningkatan \\
\cline { 3 - 4 } & & Sebelum & Sesudah & (\%) \\
\hline 1. & Bawal a.t. (C. macropomum) & $2,06 \pm 1,25^{\circ}$ & $2,50 \pm 1,80^{\circ}$ & 0,44 \\
2. & Gurami (O. goramy) & $2,32 \pm 0,31^{\mathrm{a}}$ & ND & - \\
3. & Karper (C. carpio) & $4,57 \pm 2,01^{\mathrm{a}}$ & $\mathrm{ND}$ & - \\
4. & Lele Dumbo (C. gariepinus) & $0,00 \pm 0,00^{\mathrm{b}}$ & $3,97 \pm 2,48^{\mathrm{a}}$ & 3,97 \\
5. & Nila merah (Oreochromis sp.) & $1,84 \pm 0,47^{\mathrm{b}}$ & $1,38 \pm 0,39^{\mathrm{a}}$ & $-0,46$ \\
\hline
\end{tabular}

Keterangan: Rerata dengan huruf superscript yang sama menunjukkan tidak berbeda nyata - air tawar ND : Not Determined 
Penghitungan persentase monosit pada lima spesies ikan uji menunjukkan adanya perbedaan nyata (Tabol 6). Pertbedaan tersebut tampak tidak mampengaruhi tingkat daya tahan. Sedangkan infeksi yang dilakukan pada penelitian ini tidak mengakibatkan perubahan yang signifikan pada persentase monosit.

Tabel 7 menunjukkan lima spesies ikan uji mempunyai persentase neutrofil yang relatif sama. Persentase neutrofil berkisar $1,31 \%-4,65 \%$ dan tidak terjadi perubahan yang nyata akibat infeksi.

Persentase eosinofil spesies uji relatif sama, kecuali pada Lele Dumbo yang pada pengamatan sebelum infeksi tidak ditemukan adanya eosinofil (Tabel 8). Persentase eosinofil cenderung tidak berubah karena infeksi.

Monosit, neutrofil, dan eosinofil merupakan jenis leukosit yang dapat menghancurkan bakteri melalui proses fagositosis. Namun dalam penelitian ini perbedaan persentase sel-sel fagositosis tersebut tidak berpengaruh pada daya tahan. Hal ini mengindikasikan bahwa peranan dari selsel tersebut kemungkinan lebih dipenganuhi oleh kemampuan fagositosis daripada jumlah sel. Klontz dkk., 1966 dalam Anderson, 1974 melaporkan adanya sel-sel fagositosit dari rainbow trout yang tidak dapat memfagosit $A$. hydrophila.

Jumlah leukosit dalam penelitian ini juga tidak menunjukkan pengaruh pada tingkat daya tahan. Hal ini dapat dilihat dari jumlah leukosit Gurami, Karper, Lele Dumbo, dan Nila merah yang lebih tinggi dibandingkan Bawal air tawar (Tabel 9).

Total serum merupakan persentase serum dibanding dengan total volume darah. Total serum yang tinggi secara kuantitatif menggambarkan jumlah antibodi dan faktor daya tahan lain yang tinggi pula. Namun pengamatan total serum pada penelitian ini menunjukkan bahwa perbedaan total serum tidak memberikan penganh yang nyata pada tingkat daya tahan (Tabel 10).

Tabel 9. Rerata jumlah leukosit lima spesies ikan sebelum dan tujuh hari sesudah infeksi

\begin{tabular}{|c|c|c|c|c|}
\hline \multirow{2}{*}{ No } & \multirow{2}{*}{ Spesies } & \multicolumn{2}{|c|}{ Jumlah leukosit (1000/mm } & \multirow{2}{*}{$\begin{array}{c}\text { Peningkatan } \\
\text { (\%) }\end{array}$} \\
\hline & & Sebelum & Sesudah & \\
\hline 1. & $\begin{array}{l}\text { Bawal a.t." (C. } \\
\text { macropomum) }\end{array}$ & $34,46 \pm 4,82^{b}$ & $54,90 \pm 4,41^{c}$ & 59,32 \\
\hline 2. & Gurami (0. goramy) & $78,35 \pm 14,25^{a}$ & ND & - \\
\hline 3. & Karper (C. carpio) & $44,78 \pm 7,94^{b}$ & ND & - \\
\hline 4. & Lele Dumbo (C. gariepinus) & $46,05 \pm 1,79^{\circ}$ & $90,10 \pm 3,20^{b}$ & $95,66^{* *}$ \\
\hline 5. & $\begin{array}{l}\text { Nila merah (Oreochromis } \\
\text { sp.) }\end{array}$ & $45,24 \pm 8,30^{b}$ & $188,47 \pm 26,57^{\circ}$ & $316,60^{\circ}$ \\
\hline
\end{tabular}


Tabel 10. Rerata total serum (\%) lima spesies ikan sebelum dan tujuh hari sesudah infeksi

\begin{tabular}{llccc}
\hline \multirow{2}{*}{ No } & Spesies & \multicolumn{2}{c}{ Rerata total serum (\%) } & Peningkatan \\
\cline { 2 - 4 } & \multicolumn{2}{c}{ Sebelum } & Sesudah & (\%) \\
\hline 1. & Bawal a.t."(C. macropomum) & $60,85 \pm 2,89^{\mathrm{a}}$ & $52,77 \pm 3,25^{\mathrm{a}}$ & $-8,08$ \\
2. & Gurami (O. goramy) & $44,35 \pm 2,89^{\mathrm{b}}$ & ND & - \\
3. & Karper (C. carpio) & $60,05 \pm 5,73^{\mathrm{a}}$ & ND & - \\
4. & Lele Dumbo (C. gariepinus) & $42,20 \pm 0,71^{\mathrm{b}}$ & $55,27 \pm 8,85^{\mathrm{a}}$ & 13,07 \\
5. & Nila merah (Oreochromis sp.) & $62,30 \pm 0,71^{\mathrm{c}}$ & $66,35 \pm 2,76^{\mathrm{a}}$ & 4,05 \\
\hline
\end{tabular}

Keterangan : Rerata dengan huruf superscript yang sama menunjukkan tidak berbeda nyata - : air tawar

ND : Not Determined

Tabel 11. Hasil uji daya hambat lendir lima spesies ikan terhadap infeksi A. hydrophila

\begin{tabular}{llc}
\hline No & \multicolumn{1}{c}{ Spesies } & Daya hambat lendir \\
\hline 1. & Bawal a.t."(C. macropomum) & $(-)$ \\
2. & Gurami (O. goramy) & $(-)$ \\
3. & Karper (Cy.carpio) & $(-)$ \\
4. Lele Dumbo (C. gariepinus) & $(-)$ \\
5. Nila merah (Oreochromis sp.) & $(-)$ \\
\hline Keterangan ": air tawar
\end{tabular}

Tabel 12. Kualitas air pada awal dan akhir penelitian

\begin{tabular}{llcccc}
\hline \multirow{2}{*}{ No } & \multicolumn{1}{c}{ Parameter } & \multicolumn{2}{c}{ Awal } & \multicolumn{2}{c}{ Akhir } \\
\cline { 3 - 6 } & & Kisaran & Rerata & Kisaran & Rerata \\
\hline 1. & Suhu udara $\left({ }^{\circ} \mathrm{C}\right)$ & $22-27$ & 24,35 & $24,5-31$ & 27,80 \\
2. & Suhu air $\left({ }^{\circ} \mathrm{C}\right)$ & $24-27$ & 25,40 & $25,5-29,5$ & 27,20 \\
3. & Oksigen terlarut (ppm) & $5,2-8,2$ & 6,52 & $2,6-13$ & 7,60 \\
4. & Karbondioksida bebas & $18-88$ & 40,40 & $24-100$ & 59,00 \\
& (ppm) & & & & \\
5. & Alkalinitas (ppm) & $94-114$ & 104,60 & $50-70$ & 62,70 \\
6. & Derajat keasaman $(\mathrm{pH})$ & - & - & $7,0-7,1$ & 7,02 \\
\hline
\end{tabular}

Lendir diduga mempunyai kemampuan bakterisidal (Schaperclaus, 1992 dan Ingram, 1980), namun uji daya hambat lendir terhadap A. hydrophila yang dilakukan pada penelitian ini tidak menemukan adanya kemampuan bakterisidal dari lendir (Tabel 11). Hasil yang sama juga ditunjukkan oleh hasil penelitian Subasinghe dan Sommervile (1988) pada O. mosambicus. Meskipun demikian lendir tetap mempunyai peranan penting pada daya tahan, salah satunya adalah sebagai tempat sekresi antibodi (Kawai dan Kusuda, 1981 dan Kawai dkk., 1981).
Sensitifitas lima spesies ikan uji, kecuali Bawal air tawar, terhadap A. hydrophila menjadi catatan penting bagi pengembangan budidaya ikan. Hasil penelitian ini juga menunjukkan bahwa bakteri ini masih menjadi ancaman bagi kelangsungan budidaya perikanan. Empat spesies tersebut, terutama Gurami, merupakan spesies ikan budidaya yang mempunyai nilai ekonomis yang relatif tinggi dan banyak dibudidayakan. Oleh karena itu perlu dilakukan upaya-upaya untuk mencegah dan mengurangi kerugian akibat serangan patogen ini. Upaya pencegahan yang dapat dilakukan antara lain pemberian vaksin, imunostimulan, pemeliharaan kualitas air, perbaikan 
pemeliharaan dan penanganan serta pengembangan selective breeding.

Bawal air tawar yang lebih tahan terhadap serangan A. hydrophila merupakan pilihan yang prospektif untuk dibudidayakan pada waktu dan tempat di mana sering terjadi serangan bakteri patogen ini. Namun hal ini memerlukan data yang akurat tentang peta wilayah serangan dan waktu serangan.

Tabel 12 menunjukkan bahwa kandungan karbondioksida bebas pada air penelitian relatif tinggi, $40,4 \mathrm{ppm}$ pada awal dan 59 ppm pada akhir penelitian. Namun hal ini tampak tidak berpengaruh nyata pada mortalitas ikan (bak-bak kontrol). Hal ini sesuai dengan pendapat Boyd (1979) yang menyatakan ikan dapat toleran terhadap karbondioksida bebas yang tinggi jika kandungan oksigen terlarut juga tinggi. Kandungan oksigen terlarut pada penelitian ini adalah 6,52 ppm di awal dan 7,6 ppm di akhir penelitian, kisaran yang cukup bagi ikan untuk tetap hidup dan berkembang (Boyd, 1979).

\section{Kesimpulan dan Saran}

\section{Kesimpulan}

a). Bawal air tawar mempunyai daya tahan paling tinggi, diikuti oleh Lele Dumbo, Nila merah, Gurami dan Karper. Hal ini dipengaruhi oleh perbedaan nilai titer antibodi dan persentase trombosit.

b). Lima spesies ikan tersebut juga mempunyai perbedaan pada beberapa faktor daya tahan, meskipun tidak berkorelasi dengan resistensi terhadap $A$. hydrophila. Perbedaan tersebut meliputi jumlah leukosit, persentase limfosit, monosit, eosinofil dan total serum. Persentase neutrofil relatif sama antar spesies, sedangkan pengujian daya hambat mukus tidak menunjukkan adanya aktivitas bakterisidal.

\section{Saran}

a). Bawal air tawar dapat menjadi pilihan untuk dibudidayakan pada waktu dan tempat yang sering mengalami wabah $A$. hydrophila, sedangkan pada empat spesies ikan yang lain dapat dilakukan peningkatan daya tahan melalui vaksinasi. Pemberian imunostimulan, selective breeding, dan pengelolaan lingkungan.

b). Studi tentang resistensi Bawal air tawar dan faktor-faktor lain yang berpengaruh merupakan permasalahan yang menarik untuk penelitian - penelitian selanjutnya.

\section{Daftar Pustaka}

Anderson, D.P. 1974. Fish immunology. diseases of fish $4^{\text {th }}$ edition. Snieszko, S.F. dan H.R. Axelrod (Eds.) T.F.H. Publications. Lid.. 239 hal.

Anonim. 1997. Petunjuk praktikum pelatihan karantina ikan golongan bakteri. Jurusan Perikanan Fakultas Pertanian UGM. Yogyakarta. 45 hal.

Bastiawan, D., Taukhid, M. Alifuddin, dan S. Nuryati. 1995. Uji resistensi berbagai jenis ikan budidaya : lele dumbo, Clarias gariepinus; gurami, Osphronemus goramy, mas, Cyprinus carpio; dan nila, Oreochromis niloticus terhadap infeksi cendawan Aphanomyces sp. J. Penel. Perik. Indonesia l(2): 122-130.

Boyd, C.E. 1979. Water quality in warmwater fish ponds. Auburn University. Alabama. 359 hal.

Bell, T.A., dan D.V. Lightner. 1984. IHHN virus : Infectivity and pathogenicity studies in 

Penaeus
stylirostris and
Penaeus
vannamei.
Aquaculture. 38: 185-194.

Britz, J., J.G. Van As, dan J.E. Saayman. 1985. Occurrence and distribution of Clinostomum tilapiae and Euclinostomum heterostomum metacercarial infections of freshwater fish in Venda and Lebowa, Southern Africa. J. Fish Biol. 26: 21-28.

Brown, E.E., dan J.B. Gratzek. 1980. Fish farming handbook. Avi Publishing Company, Inc. 391 hal.

Ellis, E.A. 1988. General principles of fish vaccination dalam Fish vaccination. A.E. Ellis (Eds.). Academic Press Limited. San Diego-USA. 255 hal.

Gomez, K.A. and A.A. Gomez. 1995. Prosedur statistik untuk penelitian pertanian. Diterjemahkan oleh E. Samsuddin dan J.S. Baharsyah. Universitas Indonesia Press. Jakarta. 698 hal.

Haripoernomo, R. (1986). Ketahanan ikan majalaya, sinyonya dan hybridanya terhadap serangan atau infeksi bakteri Aeromonas hydrophila. Diklat ahli usaha perikanan. Jakarta. 37 hal.

Hazen, T.C., C.B. Fliermans, R.P. Hirsch., and G.W. Esch. 1978. Prevalence and distribution of Aeromonas hydrophila in the united states. Applied. Environ. Microbiol. 36: 731-738.

Hjeimeland, K, M. Christie dan J. Raa. 1983. Skin mucus protease from rainbow trout Salmo gairdneri and its biological significancy. J. Fish Biol. 23: 13-22.

Ingram, G.A. 1980. Substances involved in the natural resistance of fish to infection - A Review. J. Fish Biol. 16: 23-60.

Jutono, J. Soedarsono, S. Hartadi, S. Kabirun, Suhadi, D., dan Soesanto. 1980. Pedoman praktikum mikrobiologi umum. Departemen Mikrobiologi Fakultas Pertanian UGM Yogyakarta. $181 \mathrm{hal}$.

Kawai, K, R. Kusuda, dan T. Itami. 1981. Mechanism of protection in ayu orally vaccinated for vibriosis. Fish Pathol. 15: 257-262.

dan R. Kusuda. 1981 Mechanism of protection in ayu orally vaccinated for vibriosis- I. protection activity in body surface mucus. Abstr. Fish Pathol. 16: 1.

Kennedy-Stoskopf, S. 1993. Immunology. Dalam Fish medicine. M.K. Stoskopf. WB Saunders Company. Philadelphia. 149159.

Klontz, G.W. 1994. Fish hematology. Dalam Techniques in fish immunology 3. J.S. Stolen, T.C. Fletcher, A.F. Rowley, J.T. Zelikoff, S.L. Kaattari, S.A. Smith (Eds.). SOS Publication. 121-131.

Llobrera, A. T., dan R. Q. Gacutan. 1987 Aeromonas hydrophila associated with uicerative disease epizootic in Laguna de Bay, Phillipines. Aquaculture. 273-278.

Leblanc, D., KR. Mittal, G.Olivier, dan R. Lallier. 1981. Grouping of motile aeromonas spesies isolated from healthy and moribund fish. Applied. Environ.Microbiol. 42: 56-60.

Madhavi,R. 1981. Comparison on the parasitics fauna of Aplocheitus panchax and A. melastigma. J. Fish Biol.17: 349-358. 
Post, G. 1983. Textbook of fish health. TFH Publications, Inc. Ltd. 256 hal.

Roberson, B.S. 1980 . Bacterial aglutination Dalam Techniques in fish immunology 1. J.S. Stolen, T.C. Fletcher, D.P. Anderson, B.S. Roberson, W.B. Van Muiswinkel. (Eds.) SOS Publication. 81-86.

Roberts, R.J. 1978. The pathophysiology and sytematic pathology of teleosts dalam Fish. Pathol. R.J. Roberts (Eds.). Bailliere Tindall. London. 59-91.

1993. Motile aeromonas septicemia Dalam Bacterial disease of fish. Inglis, V., R.J. Roberts, and N.R. Bromage (Ed.). Blackwell Scientific Publication. 312 hal.

Sarono, A., K.H. Nitimulyo, I.Y.B. Lelono Widodo, N. Thaib, E.B.S. Haryani, S. Haryanto, Triyanto, Ustadi, A.N. Kusumahati, W. Novianti, S. Wardani, Setianingsih. 1993. Hama dan penyakit ikan karantina golongan bakteri. Kerjasama Pusat Karantina Pertanian dengan Fakultas Pertanian Jurusan Perikanan UGM Yogyakarta. 91 hal.

Schaperclaus, W. 1992. Fish diseases. Vol. I. Ed. W. Schaperclaus, H. Kulow, K. Schreckenbach A.A. Balkema. Rotterdam. 596 hal.
Sindermann, C.J. 1997. Disease diagnosis and control in north American marine aquaculture. Elsevier Scientific Publishing. 329 hal

Smith, L.S. 1982. Introduction to fish physiology. TFH Publication. 352 hal.

Subasinghe, R.P. dan C. Sommerville 1988. No antibacterial properties found in buccal and skin mucus of the mouthbrooding cichlid Oreochromis mosambicus. Asian Fish Sci. 2: 109-113.

Supriyadi, H. Mangunwiryo, Maryono, dan J. Effendi. 1995. Pencegahan penyakit bakterial pada ikan gurami dengan cara vaksinasi. J. Penel. Perik Indonesia. I(4): 28-35.

O. Komaruddin, P. Taufik, Z. Jangkaru dan S. Asih. 1998. atan daya tetas telur dan sintasan larva nila (Oreochromis niloticus) dengan menggunakan obatobatan. J. Penel. Perik. Indonesia. IV(2): 8-12.

Ventura, M.T. dan J.M. Grizzle. 1987. Evaluation of portals of entry of Aeromonas hydrophila in chanel catfish. Aquaculture.65: 205-214.

Wechsler, S.J. 1984. Fish health assessment. A preliminery report on the use of impression smears of skin mucus. J. Fish Biol. 125: 365-370. 